\title{
Do Changes in Welfare and Health Policy Affect Life Satisfaction of Older Citizens in Europe?
}

\author{
Marinela Olaroiu, ${ }^{1}$ Ioana Dana Alexa, ${ }^{2}$ and Wim J. A. van den Heuvel ${ }^{3}$ \\ ${ }^{1}$ Foundation Research and Advice in Care for Elderly (RACE), Heggerweg 2a, 6176 RB Spaubeek, Netherlands \\ ${ }^{2}$ Faculty of Medicine, University of Medicine and Pharmacy "Grigore T. Popa", 16 University Street, 700115 Iasi, Romania \\ ${ }^{3}$ University Medical Centre, University of Groningen, P.O. Box 30001, 9700 RB Groningen, Netherlands
}

Correspondence should be addressed to Wim J. A. van den Heuvel; heuvelwim@hotmail.com

Received 8 May 2017; Accepted 14 August 2017; Published 25 September 2017

Academic Editor: Tomasz Kostka

Copyright ( 2017 Marinela Olaroiu et al. This is an open access article distributed under the Creative Commons Attribution License, which permits unrestricted use, distribution, and reproduction in any medium, provided the original work is properly cited.

\begin{abstract}
Objectives. Ageing of societies causes serious political concerns on well-being of old citizens and care for the (frail) old. These concerns increased with the economic crisis of 2008. In European countries policy measures were taken to deal with the consequences of this crisis. This study explores the possible effects of these measures on life satisfaction of older citizens. Methods. Life satisfaction was assessed through international surveys in 2007 and 2013 and changes in societal conditions, using eight indicators on demography, welfare, and health, are assessed in 31 European countries in 2006 and in 2014. Data are standardised and based on official, national surveys and statistics. Results. The former found that U-shape relationship between age and life satisfaction disappeared after the crisis. Negative changes in social protection and care arrangements, taken after the economic crisis, are related to low life satisfaction in old citizens. Conclusions. Various societal conditions deteriorated in 2014 as compared to 2006. Policy measures, taken due to the 2008 economic crisis, have changed societal conditions and affected life satisfaction of older citizens negatively. In countries with a rudimentary structure of health and welfare provisions old citizens could not cope with the imposed policy measures.
\end{abstract}

\section{Introduction}

For some decades, ageing in Europe causes serious political concerns on well-being and social participation of old citizens as well as on care for the (frail) old and personnel to take care for them. These concerns increased due to the economic crisis of 2008 and are related: health and need for (long-term) care affect well-being and social participation and vice versa [1-4]. Therefore, in most European countries policy measures were proposed and taken to influence consequences of the economic crisis and ageing $[5,6]$. Measures included new pension regulations, changing arrangements for long-term care and for access to social services, but the effects of such measures on society and life of citizens are unknown. This study explores which societal measures, related to the economic crisis and ageing, may have affected the life satisfaction of older citizens. Understanding the effect of such measures on life satisfaction of older citizens could inform policymakers about future measures to get a better life for old citizens [7].
Research on quality of life and life satisfaction focuses mainly on individual determinants such as age, income, marital status, health status, physical limitations, social contacts, and social participation of citizens, whose determinants mostly show a statistically significant relationship with life satisfaction [8-12].

Besides individual characteristics, the context in which people live should be taken into account, because life satisfaction is strongly context related and also depends on social comparison $[13,14]$. Therefore, some researchers argue to use vignettes to assess life satisfaction to correct for the so-called differential item functioning, a bias in self-reports caused by differences in personal and sociocultural context [15]. Although a useful method, it does not take into account societal changes over time, including cohort effects, affecting life satisfaction [16, 17]. Societal changes may have a wide effect, that is, influencing the life of many people in various countries (e.g., World War II, mass migration, or an economic crisis), while others have an effect on people living in specific 
regions or countries (e.g., an earthquake or national legislation). Comparative studies between countries have shown the influence of specific factors, such as national income, age composition, life expectancy, and welfare provisions, on life satisfaction at societal, national level [18-21]. Such studies may show "how data on well-being can help policymakers identify the groups and countries that are bearing the brunt of the economic crisis, as well as those that are holding out better than expected, and provides a new layer of evidence to aid policy decisions." [20].

Comparative research on life satisfaction worldwide shows a U-shape between life satisfaction and age, supposing a major influence of ageing itself. Young age (16-40) groups show relatively high life satisfaction, which decreases in middle age (40-65) groups but increases again in older age (65 and over) groups $[12,22,23]$. Such U-shape is found to be rather consistent [24], but it does not apply to all countries $[3,25,26]$, indicating that specific events or societal changes may affect it in different ways. This may also apply to the economic crisis, starting in 2008.

Therefore, our premise is that this economic crisis has affected the U-shape relationship between age and life satisfaction in European countries. The first research question is, has this U-shape changed and, if so, in which direction and in which European countries?

The second research question is, which societal conditions, changed by measures due to the economic crisis of 2008, are related to life satisfaction of older citizens in Europe. We focus on older citizens because these citizens may be more vulnerable to such societal changes and therefore are an important "target group" for policy measures [3]. To answer the second question one has to look at differences in changes between countries [20].

Analyses on life satisfaction at national/country level use standardised national data (e.g., Gross Domestic Product (GDP), age dependency ratio, or life expectancy) and aggregate individual data (e.g., percentage of persons with long-standing illnesses or \% of unmet health care needs). A comparative study of 27 European countries, describing changes in "a full range of subjective well-being" between 2007 and 2011 in all adult citizens, shows that GDP and percentage of people with disabilities are related to wellbeing. However, subjective well-being over time increased marginally and did not apply to all countries, indicating that national policy or culture may make a difference [20]. Although it was expected that the economic crisis of 2008 would show some effect on life satisfaction, one may argue that the time frame was too short to see such effects. A recently published study analyses changes in life satisfaction in 24 European countries between 2002 and 2012, also taking into account recent, mainly income related societal changes, including the economic crisis of 2008 [21]. Income related indicators do affect life satisfaction mostly, but their effects are not uniform over European countries. However, it was stated that "economic crises tend to be followed by crises in happiness." Our study focuses on more detailed changes, like change in life expectancy, pension, health status, and quality of care, that is, especially on changes important for older people.

\section{Methods}

To "see" effects of policy measures, related to the 2008 crisis, on "life satisfaction" one has to wait till such measures are implemented in practice and experienced by citizens. Therefore, we use the time frame between 2006 and 2014 and assessed indicators two years before the crisis was started and two years after the measures taken were fully implemented. Based on former mentioned studies, we selected societal indicators on demography, on welfare, and on health.

The research design combines changes in societal indicators over time (2006-2014) with a comparison between countries to analyse which changes in national indicators affect life satisfaction of old citizens (65 years and over) in 2013. The data are based on representative samples in each country like the data on life satisfaction or subjective health or on official, national statistics collected by Eurostat or OECD.

Life satisfaction is assessed as "the degree to which an individual judges the overall quality of his life," to be scored on a 10-point scale between "not satisfied at all" and "fully satisfied," using data of the EU-SILC AHM 2013 study [12]. To answer the first research question, life satisfaction of different age groups in 31 European countries is compared.

To answer the second research question we selected the following indicators to measure societal conditions, as independent variables:

Demographic indicators: old dependency ratio $(65+$ to population 15-64 years) [27] and life expectancy at birth [28].

Welfare indicators: \% of GDP for social protection [29], \% of GDP for long-term care [30], and aggregate replacement ratio, an indication for gross pension for 65-74 years old as compared to gross earnings of 50-59 years old [31].

Health indicators: people with very good subjective health (citizens 16 years or older) [32], \% of longstanding illnesses [33], and \% of self-reported unmet needs in health care [34].

SPSS 23 is used for data storage and analysis.

2.1. Analysis. First, we present the average life satisfaction of adult citizens in 31 European countries in 2007 and 2013.

Next, the relationship between age and life satisfaction in 31 European countries in 2013 is described; that is, is a U-shape present? The relationship between mean life satisfaction and age in 2014 is described for the following age categories: $16-24,25-34,35-49,50-64,65-74$, and 75 and over. We ranged countries in four figures.

Next, the existence of statistically significant differences in mean life satisfaction of older citizens as compared to adult citizens will be tested for 2007 and 2013. Mean paired sample test for analysis of variance is used to test the difference in life satisfaction between adult citizens till 65 years and citizens 65 years and over.

Before answering the second question "do changes in demographic, welfare, and health indicators between 2006 and 2014 affect life satisfaction in older citizens in 2013?" we present the data of the eight independent indicators 
TABLE 1: Mean scores life satisfaction per country in 2007 and 2013.

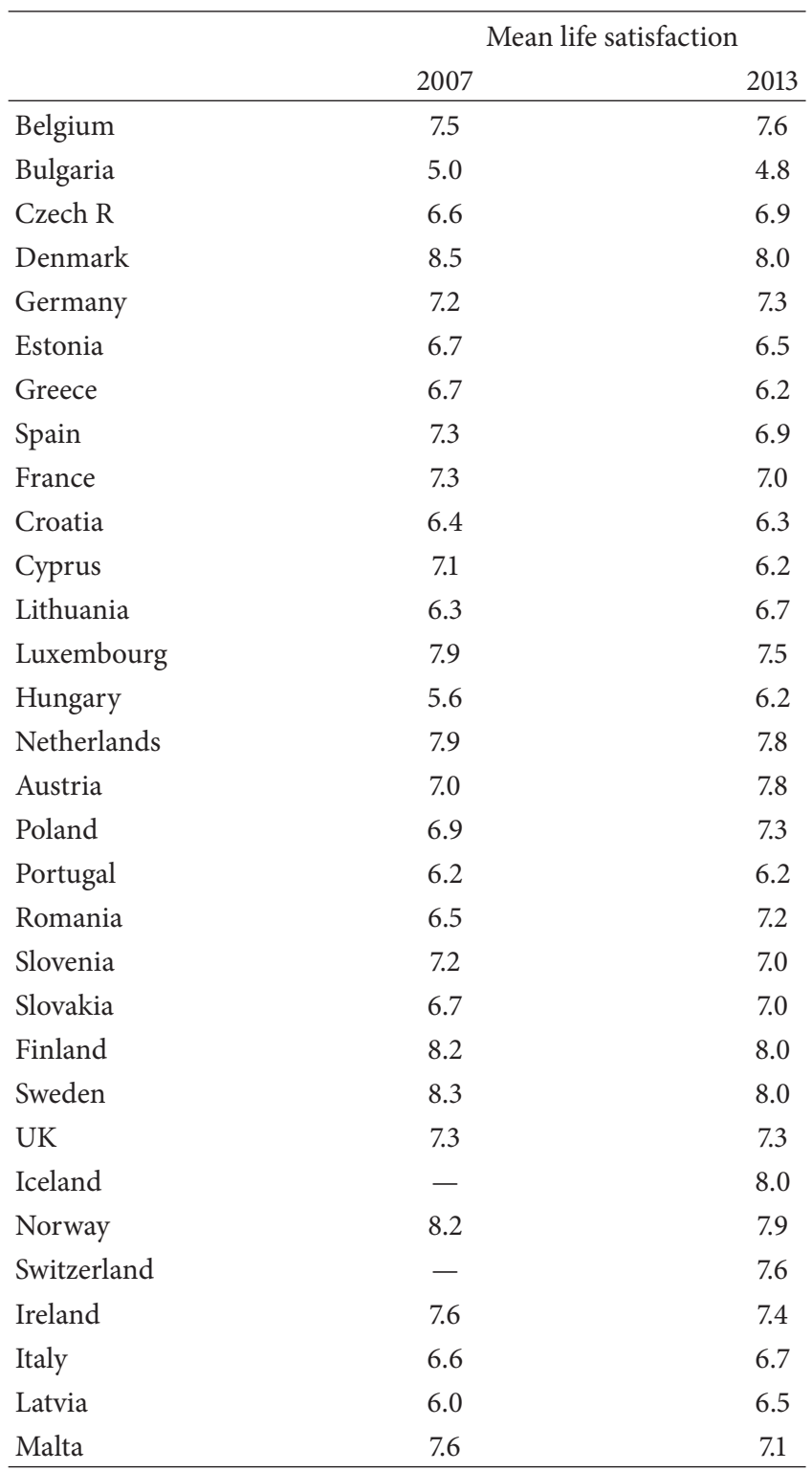

for each European country in 2006 and 2014 (Tables 2-4). Next bivariate Pearson correlations between differences in mean life satisfaction of citizens between 16 and 65 years versus 65 years and older and the independent indicators in 2014 are described. The mean differences of the eight indicators for 2006 and 2014 are calculated per country and tested on statistical significance. Significant differences are described. In the last analysis step, the influence of these mean differences (2006-2014) in indicators on life satisfaction of older citizens in 2013 is assessed, using linear regression analysis and enter method with collinearity (VIF) tested.

\section{Results}

The mean life satisfaction scores for all citizens (over 16-18 years) in 2007 and 2013 in the 31 countries are about the same 7,0 and 7,1, respectively (see Table 1). Overall, the tendency is

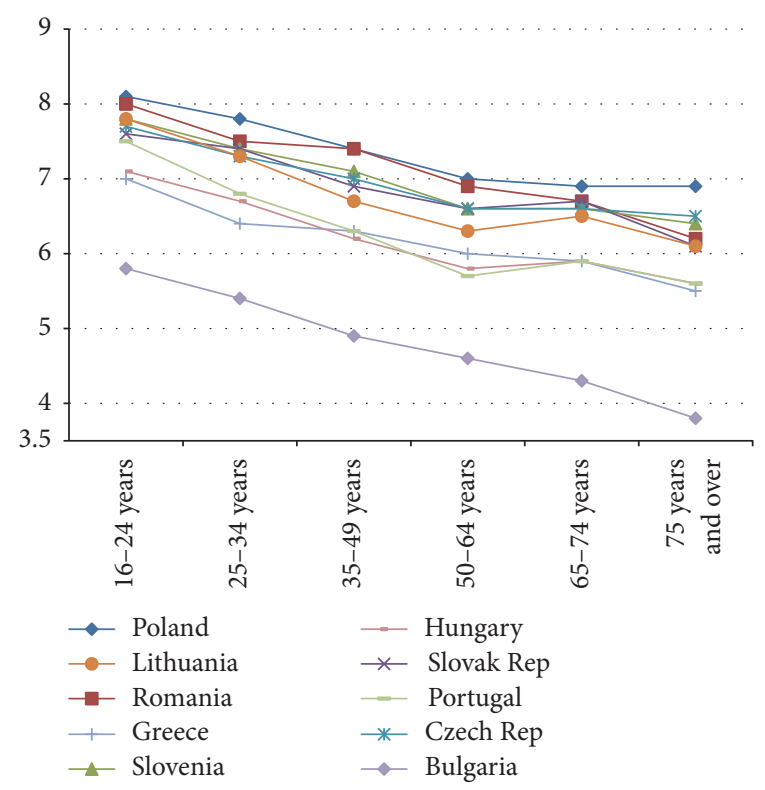

FIGURE 1: Relatively large decline in life satisfaction by age 2013.

that life satisfaction decreased in western European countries and increased in central-eastern European countries. However, some considerable differences exist between countries. Mean life satisfaction decreased with at least 0,5 points in Cyprus, Denmark, Estonia, and Malta but increased with at least 0,5 points in Austria, Hungary, Latvia, and Romania.

The relationship between age categories and mean life satisfaction per country shows that a "U-shape" does not dominate in 2013. The majority of countries (19 out of 31) show a declining line in life satisfaction from young citizens (16-24 years) to old citizens (75 years and over) (see Figures 1 and 2). Twelve countries show more or less a U-shape (see Figures 3 and 4).

The declining gradient between age and life satisfaction is most notable in Bulgaria, Croatia, Greece, Latvia, Portugal, and Romania. In Denmark, Switzerland, Sweden, Norway, and Ireland citizens in the age group 65-74 score highest in life satisfaction, where score declines in the 75 years and over age group, with the exception of Switzerland (see Figure 4). An increase in life satisfaction at 75 years and over is only found in Iceland (see Figure 3).

No statistically significant difference in mean life satisfaction is found between the two age groups (18-64 years versus 65 years and over) in 2007. The mean score on life satisfaction in 2007 applies for both age groups, that is, 7,0.

The mean life satisfaction for citizens till 65 years is 7,2 in 2013 and for citizens of 65 years and over 6,9. Analysis of variance of mean life satisfaction scores between adult citizens of 16 to 65 years and those 65 years and over in 2013 shows a statistically significant difference $(p=.003)$; that is, for old citizens the mean life satisfaction is significantly lower in 2013.

In 2013 mean differences in life satisfaction are strongly decreased in older citizens in Romania, Bulgaria, Croatia, Greece, Lithuania, Portugal, Slovenia, and Slovakia as compared to not old citizens. Increase of mean life satisfaction in 


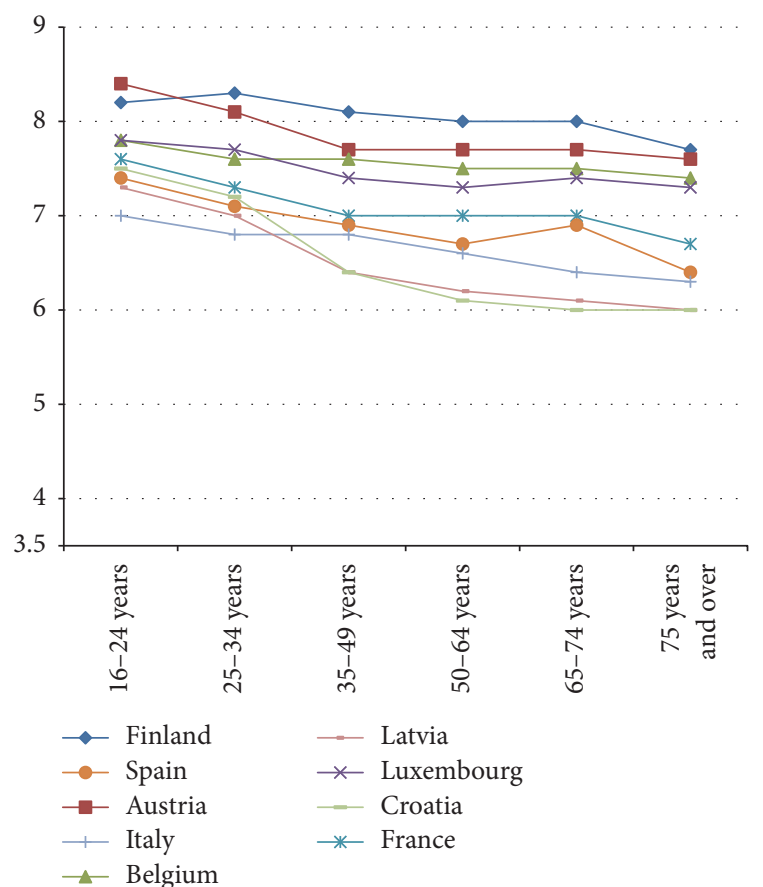

FIGURE 2: Relatively small decline in life satisfaction by age 2013.

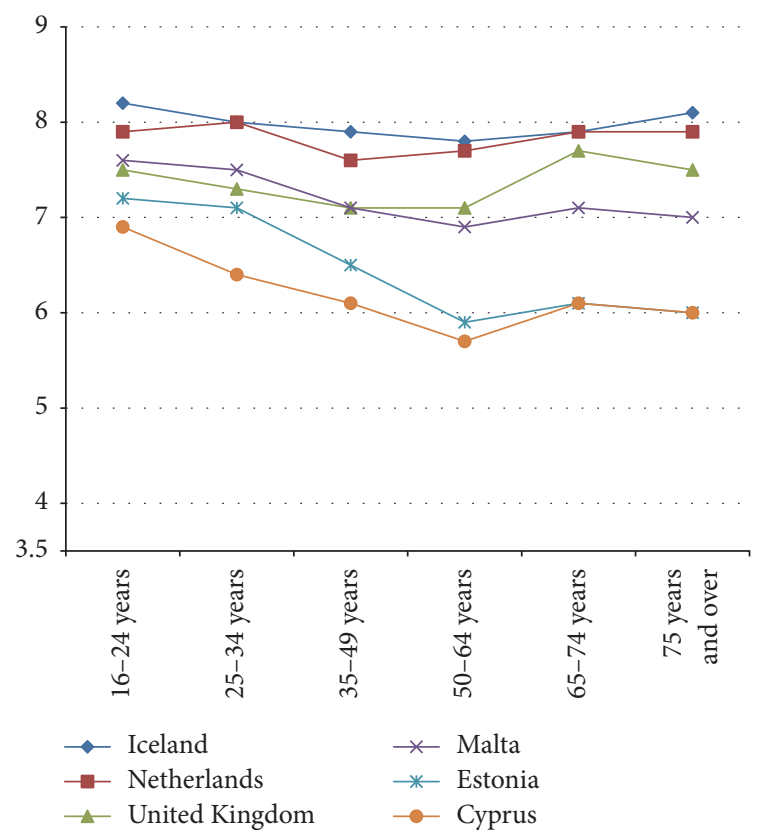

FIGURE 3: Relatively small U-shape in life satisfaction by age 2013.

older citizens as compared to young ones is rare but occurs in Denmark and Ireland.

The difference in mean life satisfaction between 2007 and 2013 is due to lower life satisfaction in older citizens in 2013.

Before answering the second research question we present the mean or proportional scores for each indicator of societal change (demographic, welfare, and health) per country (see Tables 2-4).

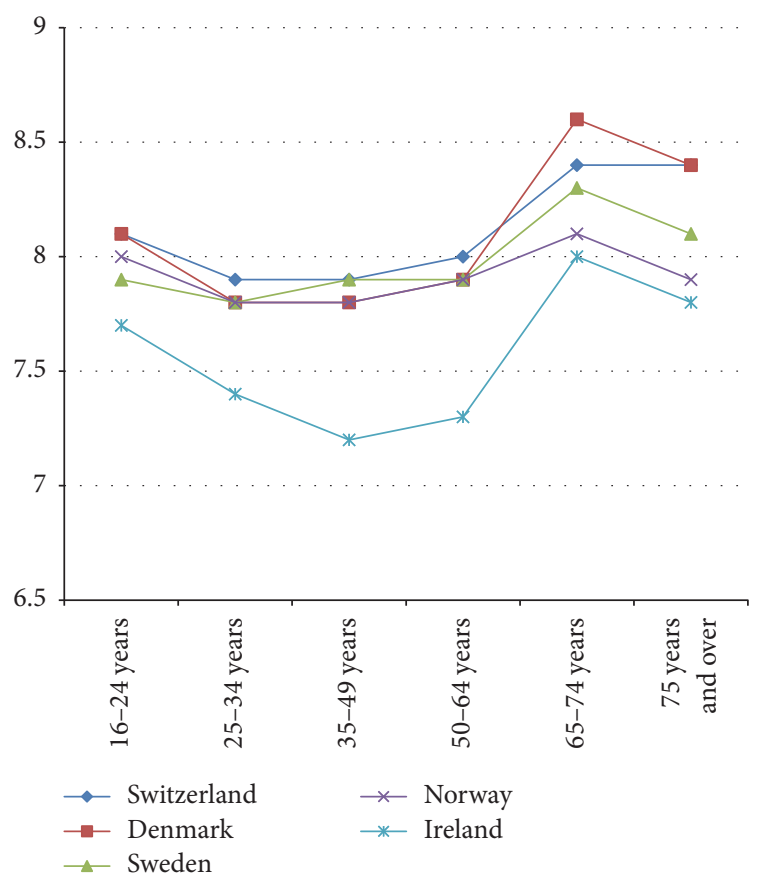

FIgURE 4: Relatively large U-shape in life satisfaction by age 2013.

The demographic indicators show an increase in the old age dependency ratio in all countries (except Luxembourg) as well as in life expectancy at birth between 2006 and 2014. The welfare indicator " $\%$ of GDP on social protection" increased in all but two (i.e., Hungary and Poland) countries. This increase was relatively strong in Cyprus, Denmark, Finland, Greece, Ireland, Netherlands, and Spain. The welfare indicator "\% GDP on long-term care expenditure" stayed on average the same in 2006 compared to 2014. The only decrease was in Romania; a strong increase occurred in Finland and Norway. The "aggregate replacement ratio" increased slightly between 2006 and 2014 in most European countries, but not in Austria, Estonia, Germany, Italy, and Sweden.

A quarter of citizens in the 31 European countries reported very good health in 2006 and in 2014. On average there is a slight decrease between 2006 and 2014. The score of this health indicator varies strongly between countries with low scores $(<10 \%)$ in Estonia, Latvia, Lithuania, and Portugal and high scores ( $>40 \%)$ in Cyprus, Greece, Iceland, and Ireland. A strong decrease in subjective health is reported in Denmark and Finland. The average proportion of long-standing illness/health problems stayed about the same between 2006 and 2014 in the 31 countries as did the proportion of self-reported unmet needs for they were too expensive. Long-standing illness/health problems were more frequently reported between 2006 and 2014 in Austria, Cyprus, Greece, Malta, and Portugal and less reported in Bulgaria and Luxembourg. Self-reported unmet needs in 2006-2014 increased strongly in Greece, Ireland, Iceland, and Italy and decreased strongly in Bulgaria, Germany, Lithuania, Poland, and Romania.

The relationship between the mean scores of the eight societal indicators in 2014 and difference in life satisfaction 
TABLE 2: Mean scores on the demographic indicators old dependency ratio and life expectancy at birth per country in 2006 and 2014.

\begin{tabular}{|c|c|c|c|c|}
\hline & \multicolumn{2}{|c|}{ Old dependency ratio $65+$ to population $15-64$ years } & \multicolumn{2}{|c|}{ Life expectancy at birth } \\
\hline & 2006 & 2014 & 2006 & 2014 \\
\hline Belgium & 26 & 27 & 79.5 & 81.4 \\
\hline Bulgaria & 25 & 29 & 72.7 & 74.5 \\
\hline Czech R & 20 & 26 & 76.7 & 78.9 \\
\hline Denmark & 23 & 28 & 78.4 & 80.7 \\
\hline Germany & 29 & 32 & 79.9 & 81.2 \\
\hline Estonia & 25 & 28 & 73.2 & 77.4 \\
\hline Greece & 28 & 32 & 79.9 & 81.5 \\
\hline Spain & 24 & 27 & 81.1 & 83.3 \\
\hline France & 25 & 28 & 80.9 & 82.8 \\
\hline Croatia & 26 & 28 & 75.9 & 77.9 \\
\hline Cyprus & 18 & 20 & 80.1 & 82.8 \\
\hline Lithuania & 24 & 27 & 71.0 & 74.7 \\
\hline Luxembourg & 21 & 20 & 79.4 & 82.3 \\
\hline Hungary & 23 & 26 & 73.5 & 76.0 \\
\hline Netherlands & 21 & 26 & 80.0 & 81.8 \\
\hline Austria & 24 & 27 & 80.1 & 81.6 \\
\hline Poland & 19 & 21 & 75.3 & 77.8 \\
\hline Portugal & 26 & 30 & 79.0 & 81.3 \\
\hline Romania & 22 & 24 & 72.5 & 75.0 \\
\hline Slovenia & 22 & 26 & 78.3 & 81.2 \\
\hline Slovakia & 16 & 19 & 74.5 & 77.0 \\
\hline Finland & 24 & 30 & 79.6 & 81.3 \\
\hline Sweden & 26 & 31 & 81.0 & 82.3 \\
\hline UK & 24 & 27 & 79.5 & 81.4 \\
\hline Iceland & 18 & 20 & 81.2 & 82.9 \\
\hline Norway & 22 & 24 & 80.6 & 82.2 \\
\hline Switzerland & 23 & 26 & 81.8 & 83.3 \\
\hline Ireland & 16 & 19 & 79.3 & 81.4 \\
\hline Italy & 30 & 33 & 81.4 & 83.2 \\
\hline Latvia & 25 & 29 & 70.6 & 74.5 \\
\hline Malta & 20 & 26 & 79.5 & 81.8 \\
\hline
\end{tabular}

between both age groups (16-64 versus 65 and over) in 2013 is explored by Pearson's correlations (see Table 5).

Older citizens $(65+)$ with higher life satisfaction as compared to younger ones (16-64) live in countries, which have a high life expectancy at birth, which spend a high percentage of their GDP on social protection and long-term care in 2014, and have a high percentage of citizens in very good health.

Next, it is analysed which societal indicators changed significantly between 2006 and 2014. The following indicators show significant mean changes between 2006 and 2013: old dependency ratio (mean 3,$26 ; p=.00$ ), life expectancy at birth (mean 2,$23 ; p=.00$ ), \% GDP social protection (mean
3,$03 ; p=.00$ ), and \% long-standing illnesses (mean 1,97; $p$ $=.05$ ). In 31 European countries the old dependency ratio increases on average with 3 points between 2006 and 2014 (with highest increase in Czech Republic, Finland, Malta, Denmark, Sweden, and Netherlands) the life expectancy over 2 years on average (with highest increase in Estonia, Latvia. Lithuania, and Slovak Republic), the percentage of GDP spent on social protection with 3\% (with highest increase in Greece, Spain, Finland, Ireland, Cyprus, Denmark, and Netherlands), and the percentage of long-standing illnesses increased with almost 2\% (with highest increase in Austria, Estonia, and Portugal). No significant mean differences between 2006 
TABLE 3: Mean scores on the welfare indicators social protection expenditure as \% of Gross Domestic Product (GDP), long-term care expenditure as \% of GDP, and aggregate replacement ratio per country in 2006 and 2014.

\begin{tabular}{|c|c|c|c|c|c|c|}
\hline & \multicolumn{2}{|c|}{$\begin{array}{l}\text { Social protection expenditure as } \% \text { of } \\
\text { GDP }\end{array}$} & \multicolumn{2}{|c|}{$\%$ GDP long-term care expenditure } & \multicolumn{2}{|c|}{$\begin{array}{l}\text { Aggregate } \\
\text { replacement ratio }\end{array}$} \\
\hline & 2006 & 2014 & 2006 & 2014 & 2006 & 2014 \\
\hline Belgium & 27 & 30 & 2.1 & 2.6 & .42 & .47 \\
\hline Bulgaria & 14 & 18 & 0.1 & 0.1 & .37 & .44 \\
\hline Czech R & 18 & 20 & 0.2 & 1.4 & .52 & .55 \\
\hline Denmark & 28 & 33 & 2.2 & 2.8 & .37 & .45 \\
\hline Germany & 28 & 29 & 1.3 & 1.6 & .46 & .45 \\
\hline Estonia & 12 & 15 & 0.2 & 0.3 & .49 & .47 \\
\hline Greece & 24 & 32 & - & 0.1 & .49 & .60 \\
\hline Spain & 20 & 26 & 0.9 & 0.9 & .48 & .60 \\
\hline France & 30 & 34 & 1.5 & 1.9 & .58 & .69 \\
\hline Croatia & 18 & 22 & - & 0.2 & - & .40 \\
\hline Cyprus & 17 & 22 & 0.2 & 0.2 & .28 & .39 \\
\hline Lithuania & 13 & 15 & 0.6 & 1.0 & .44 & .45 \\
\hline Luxembourg & 21 & 23 & 1.5 & 1.6 & .66 & .85 \\
\hline Hungary & 22 & 21 & 0.6 & 0.7 & .54 & .62 \\
\hline Netherlands & 26 & 31 & 3.4 & 4.3 & .43 & .50 \\
\hline Austria & 28 & 30 & 1.3 & 1.6 & .65 & .60 \\
\hline Poland & 20 & 18 & 0.4 & 0.4 & .59 & .63 \\
\hline Portugal & 24 & 28 & 0.1 & 0.9 & .59 & .63 \\
\hline Romania & 13 & 15 & 0.5 & 0.1 & .44 & .65 \\
\hline Slovenia & 22 & 25 & 1.1 & 1.3 & .41 & .45 \\
\hline Slovakia & 16 & 18 & 0.2 & 0.1 & .57 & .62 \\
\hline Finland & 25 & 31 & 2.1 & 4.0 & .47 & .51 \\
\hline Sweden & 29 & 30 & 3.5 & 3.5 & .62 & .60 \\
\hline UK & 26 & 28 & - & 1.8 & .45 & .51 \\
\hline Iceland & 21 & 24 & 1.8 & 1.8 & .46 & .49 \\
\hline Norway & 22 & 25 & 2.1 & 3.3 & .46 & .59 \\
\hline Switzerland & 24 & 27 & 2.0 & 2.8 & .39 & .44 \\
\hline Ireland & 17 & 22 & - & 2.2 & .38 & .36 \\
\hline Italy & 26 & 30 & - & 0.9 & .58 & .64 \\
\hline Latvia & 12 & 14 & 0.2 & 0.5 & .49 & .44 \\
\hline Malta & 17 & 18 & - & - & .45 & .56 \\
\hline
\end{tabular}

and 2014 are found for \% of GDP spent in long-term care, aggregate replacement ratio, the \% of very good subjective health, and \% of unmet needs in health care.

Regression analysis, with life satisfaction of older citizens in 2013 as dependent variable and mean differences in the eight indicators (2006-2014) as independent variables, shows that four indicators statistically significantly contribute to explaining the level of life satisfaction in older citizens, explaining $38 \%$ of the variance (see Table 6).

Low life satisfaction of older citizens (65 years and over) in 2013 occurs in countries, where life expectancy decreased as well as financial means for social protection and long-term care. In countries, where the percentage of unmet needs in health care between 2006 and 2014 increased, older citizens show low life satisfaction in 2013.

\section{Discussion}

Life satisfaction of older citizens in Europe is significantly decreased in 2013 as compared to younger age groups. Such a difference has not been found before, that is, in 2007 or $2003[20,35]$. It is interesting to note the overall tendency that life satisfaction decreased in western European countries and increased in central-eastern European countries, but it seems that in the later countries younger age groups are more satisfied as compared to older ones. The former found that 
TABLE 4: Mean scores on the health indicators subjective health, percentage of long-standing illness/health problem, and percentage of selfreported unmet needs because they were too expensive per country in 2006 and 2014.

\begin{tabular}{|c|c|c|c|c|c|c|}
\hline & \multicolumn{2}{|c|}{$\%$ Subjective health (very good) } & \multicolumn{2}{|c|}{$\begin{array}{c}\text { \% Long-standing illness/health problem } 16 \\
\text { years and over }\end{array}$} & \multicolumn{2}{|c|}{$\begin{array}{l}\text { \% Self-reported unmet needs, } \\
\text { reason: too expensive, } 16 \text { years } \\
\text { and over }\end{array}$} \\
\hline & 2006 & 2014 & 2006 & 2014 & 2006 & 2014 \\
\hline Belgium & 28 & 30 & 25 & 26 & 0.4 & 2.2 \\
\hline Bulgaria & 21 & 17 & 30 & 20 & 16.3 & 4.4 \\
\hline Czech R & 19 & 19 & 30 & 29 & 0.2 & 0.5 \\
\hline Denmark & 41 & 27 & 29 & 27 & 0.2 & 0.4 \\
\hline Germany & 14 & 17 & 39 & 39 & 4.2 & 0.6 \\
\hline Estonia & 7 & 11 & 34 & 46 & 2.7 & 0.5 \\
\hline Greece & 51 & 45 & 18 & 21 & 4.5 & 9.7 \\
\hline Spain & 17 & 17 & 23 & 28 & 0.2 & 0.5 \\
\hline France & 25 & 24 & 34 & 36 & 1.3 & 2.3 \\
\hline Croatia & 17 & 25 & - & 31 & - & 1.4 \\
\hline Cyprus & 49 & 45 & 28 & 34 & 3.0 & 4.6 \\
\hline Lithuania & 6 & 7 & 34 & 29 & 4.7 & 0.7 \\
\hline Luxembourg & 32 & 25 & 25 & 18 & 0.2 & 0.6 \\
\hline Hungary & 13 & 18 & 35 & 35 & 1.5 & 2.1 \\
\hline Netherlands & 21 & 23 & 32 & 35 & 0.1 & 0.4 \\
\hline Austria & 37 & 32 & 21 & 37 & 0.4 & 0.1 \\
\hline Poland & 15 & 17 & 34 & 38 & 5.6 & 3.1 \\
\hline Portugal & 7 & 8 & 30 & 40 & 3.4 & 3.0 \\
\hline Romania & 25 & 28 & 19 & 18 & 11.0 & 8.2 \\
\hline Slovenia & 16 & 21 & 37 & 32 & 0.0 & 0.1 \\
\hline Slovakia & 23 & 20 & 26 & 28 & 2.1 & 0.9 \\
\hline Finland & 44 & 21 & 39 & 42 & 1.0 & 0.1 \\
\hline Sweden & 34 & 33 & 35 & 32 & 0.9 & 0.5 \\
\hline UK & 33 & 32 & 38 & 33 & 0.1 & 0.1 \\
\hline Iceland & 50 & 40 & 25 & 30 & 0.8 & 3.4 \\
\hline Norway & 28 & 32 & 31 & 35 & 0.4 & 0.2 \\
\hline Switzerland & 25 & 33 & 34 & 36 & 0.9 & 1.0 \\
\hline Ireland & 47 & 43 & 25 & 28 & 1.2 & 6.2 \\
\hline Italy & 13 & 14 & 23 & 24 & 3.0 & 7.0 \\
\hline Latvia & 3 & 4 & 36 & 41 & 11.7 & 10.5 \\
\hline Malta & 31 & 20 & 20 & 28 & 1.4 & 0.9 \\
\hline
\end{tabular}

TABLE 5: Pearson correlations between eight explaining variables and the difference of mean life satisfaction of citizens under 65 years versus over 64 years in 2013.

\begin{tabular}{|c|c|c|c|c|c|c|c|c|}
\hline & $\begin{array}{c}\text { Old } \\
\text { dependency } \\
\text { ratio }\end{array}$ & $\begin{array}{c}\text { Life } \\
\text { expectancy at } \\
\text { birth }\end{array}$ & $\begin{array}{c}\% \text { GDP for } \\
\text { social } \\
\text { protection }\end{array}$ & $\begin{array}{c}\% \text { GDP for } \\
\text { long-term care }\end{array}$ & $\begin{array}{c}\text { Aggregate } \\
\text { replacement } \\
\text { ratio }\end{array}$ & $\begin{array}{c}\text { \% very good } \\
\text { subjective } \\
\text { health }\end{array}$ & $\begin{array}{c}\text { \% long } \\
\text { standing } \\
\text { illness }\end{array}$ & $\begin{array}{c}\% \text { unmet } \\
\text { needs health } \\
\text { care }\end{array}$ \\
\hline $\begin{array}{l}\text { Difference in } \\
\text { life satisfaction } \\
16-64 \text { versus } \\
65+\end{array}$ & -.114 & .608 & .463 & .689 & -.242 & .478 & .149 & -.315 \\
\hline $\begin{array}{l}\text { Significance } \\
\text { level }\end{array}$ & .542 & .000 & .009 & .000 & .190 & .007 & .423 & .084 \\
\hline
\end{tabular}


TABLE 6: Regression analysis and enter method, between changes in independent variables between 2006 and 2014 and life satisfaction of citizens of 65 years and older in 2013 as dependent variable in 31 European countries.

\begin{tabular}{|c|c|c|c|c|c|}
\hline \multirow{2}{*}{ Life satisfaction of older citizens $65+$ in 2013} & \multicolumn{2}{|c|}{ Unstandardised coefficients } & \multirow{2}{*}{$\begin{array}{l}\text { Standardised coefficients } \\
\text { Beta }\end{array}$} & \multirow{2}{*}{$t$} & \multirow{2}{*}{ Significance } \\
\hline & $\mathrm{B}$ & Standard error & & & \\
\hline Constant & 8.699 & .696 & & 12.491 & .000 \\
\hline Difference in old dependency ratio 2006-2014 & -.079 & .116 & -.120 & -.685 & .501 \\
\hline Difference in life expectancy 2006-2014 & -.521 & .225 & -.368 & -2.318 & .030 \\
\hline Difference in \% GDP social protection 2006-2014 & -.188 & .082 & -.386 & -2.292 & .032 \\
\hline Difference in \% GDP long-term care 2006-2014 & .776 & .332 & .378 & 2.335 & .029 \\
\hline Difference in aggregate replacement ratio 2006-2014 & -.406 & 2.693 & -.025 & -.151 & .882 \\
\hline Difference in \% subjective health as very good 2006-2014 & -.042 & .025 & -.275 & -1.682 & .107 \\
\hline Difference in \% long standing illnesses 2006-2014 & -.042 & .032 & -.220 & -1.326 & .199 \\
\hline Difference in \% unmet needs in health care $2006-2014$ & .173 & .053 & .515 & 3.281 & .003 \\
\hline
\end{tabular}

U-shape between age and life satisfaction (i.e., older citizens' life satisfaction is relatively higher as compared to middle age citizens and about the same as in younger citizens) does not apply for most European countries in 2014. There are exceptions like in Denmark, Ireland, Norway, Sweden, and Switzerland where life satisfaction of citizens between 65 and 74 years is higher than young age groups. However, in four of these countries, all with a high life expectancy at birth above 81 years, life satisfaction of citizens of 75 years and older decreased. So, policy measures taken between 2006 and 2014 could have affected life satisfaction of older citizens negatively. A different pattern in life satisfaction scores among the oldest is formerly noticed [15] but not understood yet. Probably, the most vulnerable old citizens suffer first from policy measures, which reduce welfare and health services.

The different patterns between age and life satisfaction in different countries indicate that not only individual factors could explain such variations. Longitudinal data of individual old citizens show that disfavoured living conditions (housing and neighbourhoods) are related to lower life satisfaction [1]. Therefore, it is important to look for the dynamics of these conditions on aggregate level to investigate the influence of policy measures on life satisfaction as stated in the third quality of life survey in Europe [20]. Our study shows that significant changes in societal indicators, related to the ageing of the population in combination with the economic crisis, occurred in European countries between 2006 and 2014. Relatively less investment in social protection and long-term care affected negatively life satisfaction of older citizens as did decline in quality of care (low increase in life expectancy and increase of unmet needs). The second quality of life survey in Europe showed that material deprivation and health status were the most important influences on life satisfaction at individual level [35]. Our outcomes suggest that also policy measures taken at national level affect life satisfaction of the most vulnerable citizens, like old citizens, directly. However, this applies especially in countries, which already have a back-log in economics and welfare. Many central-eastern European countries have arrears in social protection and quality of care, as compared to more prosperous northwestern European countries with long-standing social welfare provisions. Therefore, in these countries, older citizens show more frequently a lower life satisfaction as compared to young and middle aged citizens.

As all studies, our study has shortcomings. Most evident is that not all, theoretically possible, indicators for societal changes could be included, because of the limited indicators in international data bases. The same goes for the time period. The time period is partly determined by the available data in specific years. Nevertheless, we have argued that the chosen years 2006 and 2014 are adequate. In 2006 a financial crisis was not discussed or visible. In 2014, the policy measures were implemented and people were confronted with the consequences, especially older citizens because of intervention in welfare and care facilities.

A strong point of the study is that the collected data are comparative, not only in time, but also in method of data collection and in validity of the measurements. For international, comparative research data from Eurostat or OECD are reliable, valid, and (mostly) free available.

Most studies on life satisfaction and ageing use individual indicators as explaining factors to understand variance in life satisfaction [20,35]. Rather innovative is that we use aggregate indicators on national level, including 31 European countries, to understand changes in life satisfaction in older citizens.

Based on this study we conclude that life satisfaction of old citizens deteriorated related to policy measures, taken because of the economic crisis of 2008 and ageing of the population in Europe. These measures have changed various societal conditions negatively.

Nevertheless, some societal indicators show that social conditions clearly improved in some countries but others got worse. For example, the percentage of reported unmet needs decreased significantly in Bulgaria, Lithuania, Romania, Poland, and Estonia between 2006 and 2014 but it is not said that old citizens profited most. In Ireland, Greece, Italy, Iceland, and Belgium unmet needs in health care were more often reported. Based on our analysis, we believe that the rudimentary structure of health and welfare provisions in various central-eastern European countries still were too vulnerable to cope with the imposed policy measures and not because of attitudes or belief systems [18]. At the same time, it should be stated that knowledge and understanding on how 
societal processes and policy measures affect quality of life of citizens are limited. Theoretical development is still poor, especially when it comes to the interaction between policy measures, societal changes (including ageing of societies), and individual preferences and behaviour. International, comparative research, based on sound theoretical concepts, is strongly needed.

\section{Conflicts of Interest}

The authors declare that there are no conflicts of interest.

\section{References}

[1] G. Netuveli, R. D. Wiggins, Z. Hildon, S. M. Montgomery, and D. Blane, "Quality of life at older ages: evidence from the English longitudinal study of aging (wave 1)," Journal of Epidemiology and Community Health, vol. 60, pp. 357-363, 2006.

[2] L. Koots-Ausmees and A. Realo, "The association between life satisfaction and self-reported health status in Europe," European Journal of Personality, vol. 29, pp. 647-657, 2015.

[3] A. Steptoe, A. Deaton, and A. A. Stone, "Subjective wellbeing, health, and ageing," The Lancet, vol. 385, pp. 640-648, 2015.

[4] J. Zoetemeijer, "Life satisfaction of disabled and non-disabled elderly in Europe. Optimal saving and insurance for old age: The role of public long-term care insurance," Netspar The Netherlands, 2016.

[5] EC., "Ageing Report . Dealing with the impact of an ageing population in the EU," Communication European Commission, 2009.

[6] R. Ervik and T. Skogedal Lindén, "The making of ageing policy," in Theory and practice is Europe, Edwar Elgar Publishing Ltd, Cheltendam, UK, 2013.

[7] M. Durand, Foreword in: OECD Guidelines for Measuring Subjective Well-Being, OECD, Paris, France, 2013.

[8] K. K. Markides and H. W. Martin, "A causal model of life satisfaction among the elderly," The Journals of Gerontology, vol. 34, pp. 86-93, 1979.

[9] J. Allen, "Older people and wellbeing," Report of the Institute for Public Policy Research, 2008.

[10] N. L. Chappell and H. A. Cooke, "Age related disabilities - aging and quality of life," International Encyclopedia of Rehabilitation, 2010, http://cirrie.buffalo.edu/encyclopedia/en/article/189.

[11] C. Tieman, C. Lysack, S. Neufeld, and P. A. Lichtenberg, "Community engagement: an essential component of wellbeing in older African-American adults," International Journal of Aging \& Human Development, vol. 77, pp. 233-257, 2013.

[12] Analytical Report on Subjective Well-Being, Eurostat, Luxembourg, 2016.

[13] L. K. George, "Still happy after all these years: Research frontiers on subjectivewell being in later life," Journal of Gerontology, Series B: PsychologicalSciences \& Social Sciences, vol. 65B, pp. 331-339, 2010.

[14] EU. Data validation report, "Analysis and preparation for the dissemination of the data on wellbeing and quality of life of individuals living in the EU," D.B.1 European Union, Luxembourg, 2013.

[15] V. Angeline, D. Cavapozzi, L. Corazzini, and O. Paccagnella, "Age, health and life satisfaction among older europeans," Social Indicators Research, vol. 105, pp. 293-308, 2012.
[16] O. Lelekes, "Happiness across the life cycle: Exploring agespecific preferences," European Centre. Policy Brief (2), 2008.

[17] A. Realo and H. Dobewall, "Does life satisfaction change with age? A comparison of Estonia, Finland, Latvia, and Sweden," Journal of Research in Personality, vol. 45, pp. 297-308, 2011.

[18] S. Djankov, E. Nikolova, and J. Zilinsky, "The happiness gap in eastern Europe," The European Bank for Reconstruction and Development. Working paper no 184 London, 2016.

[19] J. Helliwell, R. Layard, and J. Sachs, World Happiness Report 2016, Update, vol. I, Sustainable Development Solutions Network, New York, NY, USA, 2016.

[20] Eurofound., "Third quality of life survey in Europe: subjective well-being," State of health in the EU Cycle, OECD, Paris, 2016.

[21] K. Kubaca, Europe in times of distress: assessing life satisfaction from 2002 to 2012 [Ph.D. thesis], University of Leicester, United Kingdom, 2017.

[22] D. G. Blanchflower and A. J. Oswald, "Is well-being U-shaped over the life cycle?” IZA Discussion Papers, vol. 3075, 2007.

[23] H. Schwandt, Unmet Aspirations as an Explanation for the Age $U$-shape in Wellbeing, Center for Health and Wellbeing, Princeton Universit, Princeton, NJ, USA, 2014.

[24] R. Calvo, D. Carr, and C. Matz-Costa, "Another Paradox? The life satisfaction of older Hispanic immigrants in the United States," Journal of Aging and Health, vol. 29, pp. 3-24, 2017.

[25] C. Wundera, A. Wiencierzb, J. Schwarzec, H. Küchenhoffb, S. Kleyerb, and P. Bleningerb, "Well-being over the life span: Semiparametric evidence from British and German longitudinal data," Review of Economics and Statistics, vol. 95, no. 1, pp. 154-167, 2009.

[26] C. Graham and J. Ruiz Pozuelo, "Happiness, stress, and age: how the U-curve varies across people and places," Journal of Population Economics, no. 30th, 2016.

[27] http://ec.europa.eu/eurostat/tgm/table.do?tab=table\&amp;init= 1\&amp;language $=$ en \&amp;pcode $=$ tsdde510\&amp;plugin $=1$ ).

[28] http://appsso.eurostat.ec.europa.eu/nui/show.do?dataset=demo_ mlexpec\&amp;lang=en.

[29] http://ec.europa.eu/eurostat/statistics-explained/index.php/Social_ protection_statistics.

[30] http://ec.europa.eu/eurostat/statistics-explained/index.php/File: Longterm_care_expenditure,_2014_YB17.png.

[31] http://ec.europa.eu/eurostat/tgm/table.do?tab=table\&amp;init= 1\&amp;language $=$ en \&amp;pcode $=$ tsdde310\&amp;plugin $=1$.

[32] http://appsso.eurostat.ec.europa.eu/nui/show.do?dataset=hlth silc_01\&amp;lang=en.

[33] http://appsso.eurostat.ec.europa.eu/nui/show.do?dataset=hlth_ silc_05\&amp;lang=en.

[34] http://ec.europa.eu/eurostat/statistics-explained/index.php/Unmet_health_care_needs_statistics.

[35] D. Watson, F. Pichler, and C. Wallace, Second European Quality of Life Survey Subjective well-being in Europe. Research institute: ESRI, Dublin, and University of Aberdeen. Luxembourg. 2010. 


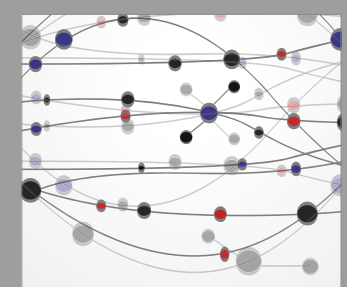

The Scientific World Journal
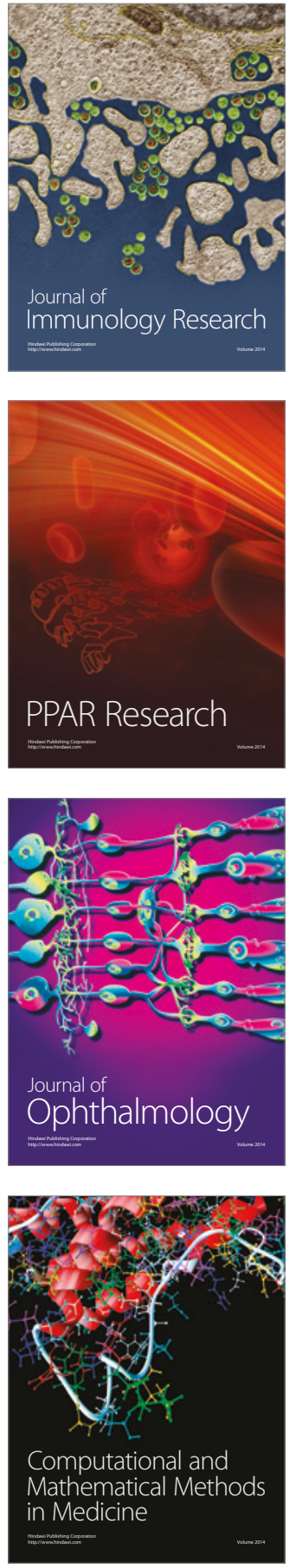

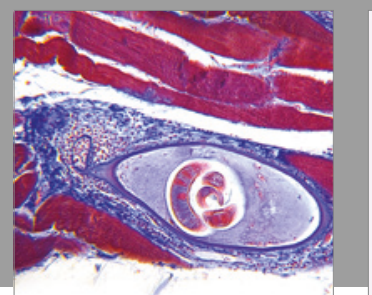

Gastroenterology Research and Practice
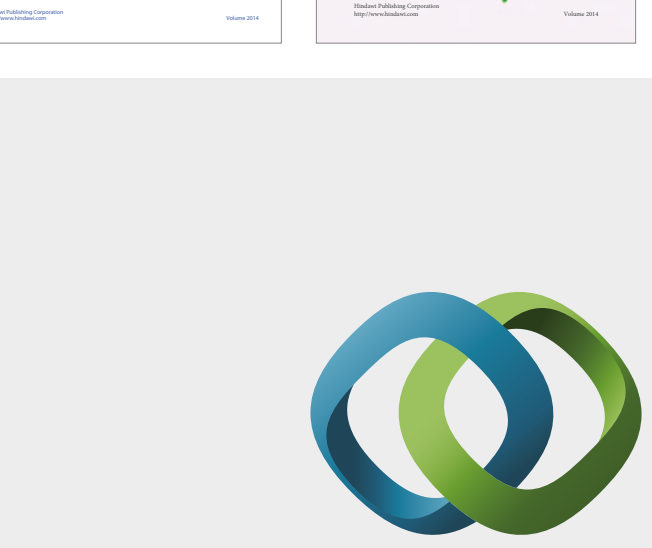

\section{Hindawi}

Submit your manuscripts at

https://www.hindawi.com
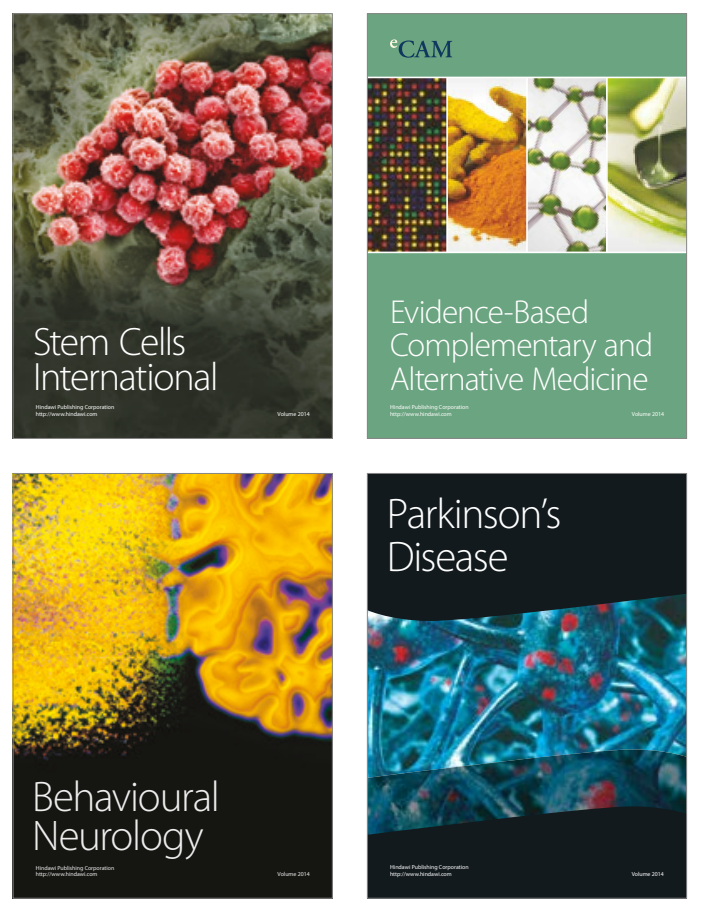
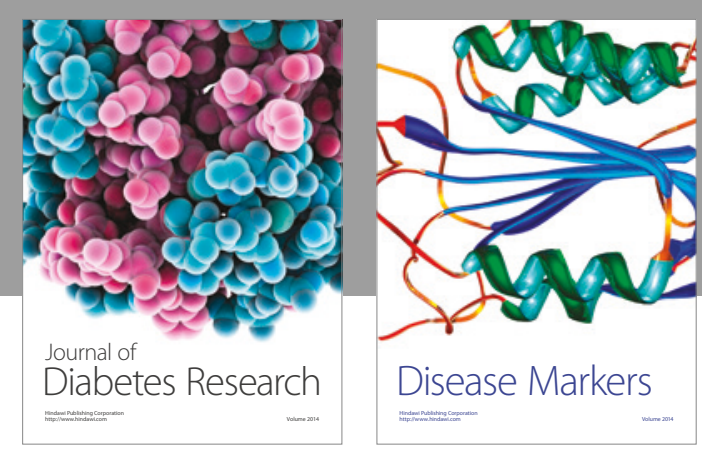

Disease Markers
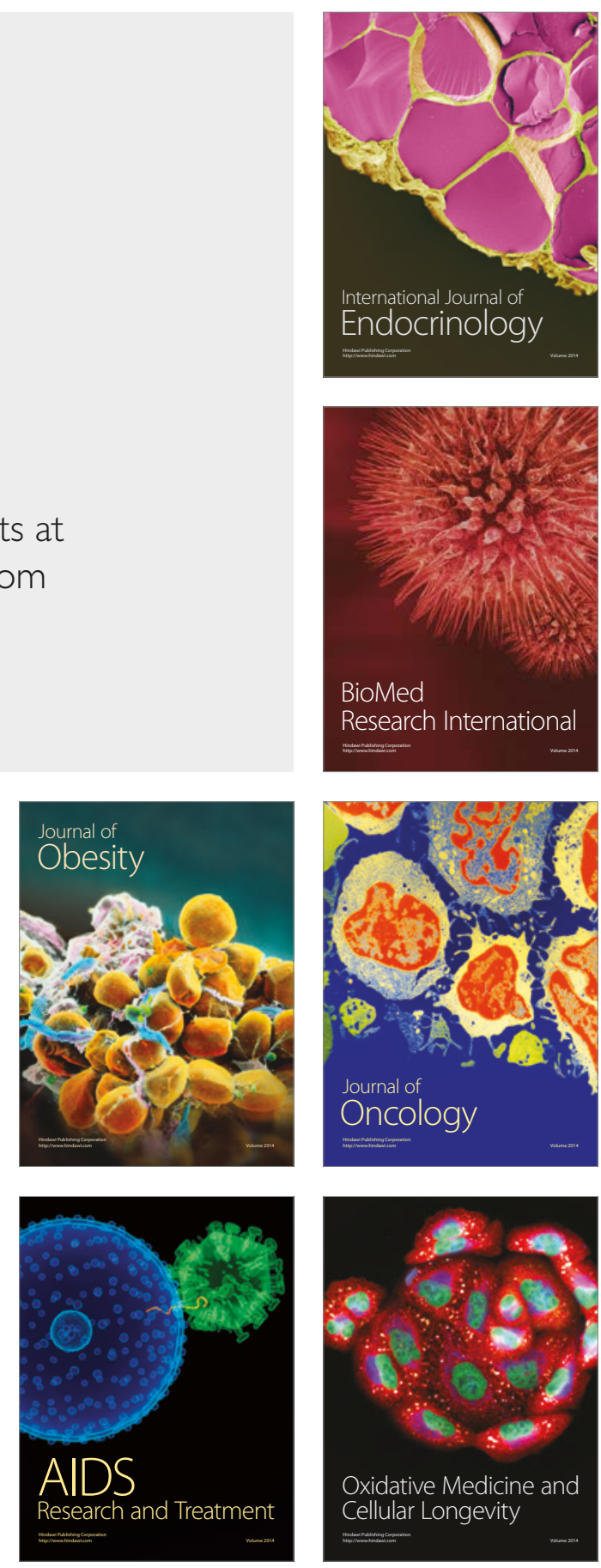